\title{
STUDIES ON GERMLING DEVELOPMENT AND LIFE-HISTORY IN ULVACEAE AND MONOSTROMACEAE -PART I-
}

\author{
$\operatorname{AUTHOR}(S)$ :
}

Yoshida, Keisei

\section{CITATION:}

Yoshida, Keisei. STUDIES ON GERMLING DEVELOPMENT AND LIFE-HISTORY IN ULVACEAE AND MONOSTROMACEAE -PART I-. PUBLICATIONS OF THE SETO MARINE BIOLOGICAL LABORATORY 1970, 17(6): 403-428

\section{ISSUE DATE:}

1970-03-31

URL:

http://hdl.handle.net/2433/175614

RIGHT: 


\title{
STUDIES ON GERMLING DEVELOPMENT AND LIFE-HISTORY IN ULVACEAE AND MONOSTROMACEAE PART I, ${ }^{1,2}$
}

\author{
KEISEI YOSHIDA
}

Suma Aquarium of Kobe City

With 9 Text-figures

\section{CONTENTS}

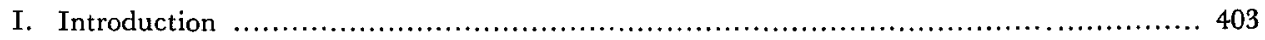

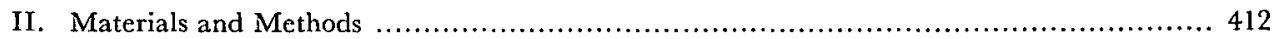

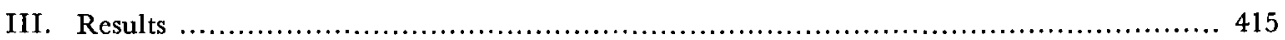

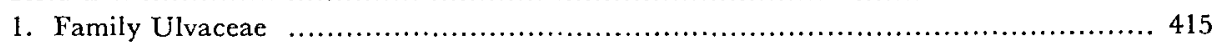

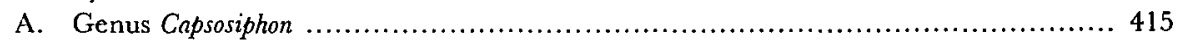

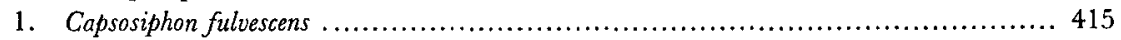

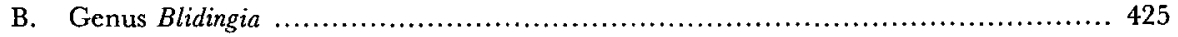

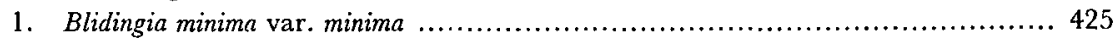

\section{INTRODUCTION}

In Japan, many species of green algae belonging to the Ulvaceae and Monostromaceae are important from the viewpoint of fishery, either as edible or noxious plants. Two species of Monostroma, viz., $M$. nitidum and $M$. latissimum, are used as a preserved food called "Nori-no-tsukudani", being boiled down with soy. These Monostroma species are now cultivated mainly on the western Pacific coast of Japan. Along the coasts of Ise and Mikawa Bay, the cultivation grounds for Monostroma are laid out extensively, but in other areas the harvest of Monostroma is perceived merely as a by-product of the Porphyra cultivation. Several species of the Ulvaceae, for instance Enteromorpha prolifera, E. linza, are used to prepare a dry food called "Aonori". Among them, E. prolifera is collected on the coasts of eastern and western Japan, namely in Miyagi Prefecture and along the coast of Seto Inland Sea.

According to Kato, Mryazaki and Honda (1958), the annual yield of $E$. prolifera in Tokushima Prefecture amounts to about $190,000 \mathrm{~kg}$ and $40,000,000 \mathrm{Yen}$, and cultivation of this alga on a large scale is now being planned in that prefecture with some preliminary investigations started already. According to the Annual Reports

1) Contributions from the Seto Marine Biological Laboratory, No. 518.

2) Contributions from the Suma Aquarium of Kobe City, No. 73.

Publ. Seto Mar. Biol. Lab., XVII (6), 403-428, 1970 . (Article 25) 
of Statistics on Fisheries for 1964, the yield of "Aonori" prepared from Monostroma and Enteromorpha was estimated to be as many as 196,895,000 sheets of dried preparations, the so-called "Aoita", and as much as 824 million Yen in price (Table 1). Ueda, Iwamoto and Miura (1963) estimated the yield of Monostroma to be one half of the above-mentioned total value.

Table 1. Regional and prefectural annual yields of "Aonori" for 1964* in number of the unit amount which consists of 1000 sheets of the dried product called "Ao-ita".

\begin{tabular}{|c|c|}
\hline Hokkaido Region. . ............................... & $\mathbf{0}$ \\
\hline Northern Pacific Region. .................. & 7.249 \\
\hline Miyagi Pref. ................. & 3,454 \\
\hline Fukushima Pref. ................. & 3,796 \\
\hline Middle Pacific Region. ................... & 117,831 \\
\hline Chiba Pref. & 6,129 \\
\hline 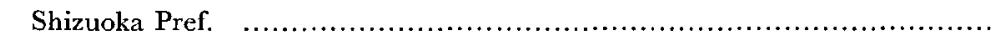 & 10,716 \\
\hline Aichi Pref. ........................... & 82,961 \\
\hline 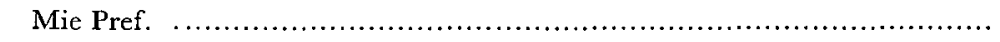 & 17,803 \\
\hline Southern Pacific Region. ... & 687 \\
\hline Ehime Pref. $\ldots \ldots \ldots \ldots \ldots \ldots \ldots$ & 687 \\
\hline Northern Japan Sea Region ... & $\mathbf{0}$ \\
\hline Western Japan Sea Region. & $\mathbf{0}$ \\
\hline East China Sea Region.. & 34,316 \\
\hline Fukuoka Pref. .......... & 19,604 \\
\hline Saga Pref. ................ & 8 \\
\hline Nagasaki Pref. ............ & 2,891 \\
\hline Kumamoto Pref. ... & 11,398 \\
\hline 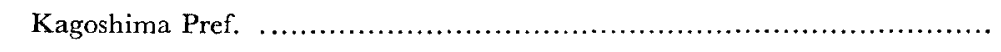 & 415 \\
\hline Seto Inland Sea Region................ & 36,812 \\
\hline Wakayama Pref. .......... & 1,330 \\
\hline Hyogo Pref. ....................... & 420 \\
\hline 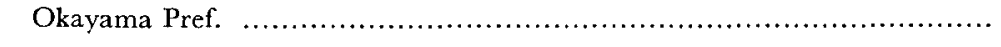 & 40 \\
\hline 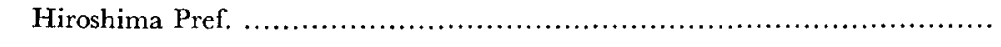 & 803 \\
\hline Yamaguchi Pref. ...... & 834 \\
\hline Tokushima Pref. . & 17,692 \\
\hline Kagawa Pref. ................... & 65 \\
\hline Ehime Pref. $\ldots \ldots \ldots \ldots \ldots \ldots \ldots \ldots \ldots \ldots \ldots \ldots \ldots \ldots \ldots \ldots$ & 15,164 \\
\hline 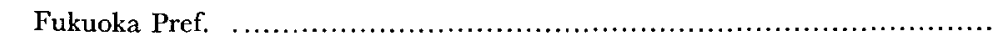 & 362 \\
\hline 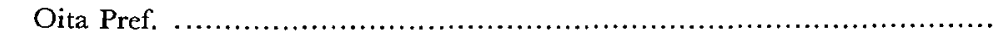 & 103 \\
\hline 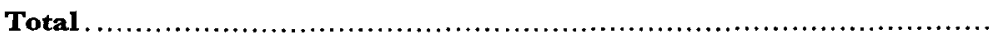 & 196,895 \\
\hline onding to $824,000,000$ Yen in price) & \\
\hline
\end{tabular}

* According to the Annual Reports of Statistics on Fisheries for 1964, 41-13: p. 252, published by the Ministry of Agriculture and Forestry. 
The algae belonging to the genus Ulva are used to feed domestic animals and also as a manure. They are collected to manufacture a kind of feed which is marketed in Chiba and Aichi prefectures.

On the other hand, many species of the Ulvaceae and Monostromaceae grow on the culture-nets of Porphyra (purple laver) which is one of the most important marine products in Japan, and sometimes they impede the growth of Porphyra. Moreover, the more densely these green algae are mixed in the dried preparations of Porphyra or "Hoshi-nori", the lower becomes the commercial value of the latter. Among the algae growing on the culture-nets of Porphyra the following species are most conspicuous: Capsosiphon fulvescens, Blidingia marginata, Enteromorpha prolifera, E. compressa, E. bulbosa, E. linza, Monostroma latissimum, $M$. nitidum and $M$. grevillei. So the studies on the life-history and classification of these species are not only interesting but also urgently needed from the viewpoint of phycology and fisheries.

To begin with, a review of previous studies on Monostroma and allied genera is given in the following lines. REINKE (1878) observed that the zygotes of M. bullosum increased in size without cell-divisions and became the cysts. The same fact was confirmed in $M$. latissimum by Carter (1926) and in Monostroma sp. by Mryake and Kunieda (1931). Kunieda (1934) studied a species of Monostroma from Misaki, and reported that the cysts derived from the zygotes discharged a large number of 4flagellate zoospores after about six months since their birth and these zoospores developed into filamentous thalli which grew finally into flat sporelings or young Monostroma plants. As a result, he maintained that the Monostroma should be removed from the Ulvaceae to a new family "Monostromaceae" which is characterized by such a unique type of life-history as briefly explained above. He also described that the new family seemed to have some relation with "Chlamydomonadaceae".

Afterwards, the same results as Kunieda's were reported by Yamada \& Saito (1938) in $M$. angica:a, by Möwus (1938) in $M$. wittrockii, and by ARASAKr (1946, 1949) in M. nitidum and $M$. latissimum. Möwus (1938) investigated the life-history of $M$. wittrockii from Naples and reported that one-half of the number of thalli developed from the zoospores liberated from a single cyst belonged to one sex and one-half to the opposite sex, and that the reduction division was consequently proved to have taken place at the zoospore formation in the cyst. He also confirmed in the same species that the gametes could germinate directly or parthenogenetically into the sexual thalli of just the same sex as the gametes. Prior to that report, Bliding (1935) observed in $M$. wittrockii from the western coast of Sweden that the 2-flagellate swarmers grew directly into thalli, and he presumed that the swarmers were parthenogametes. Recently, the same result as BLIDING's was reported by KIDA (1964) in M. wittrockii from Ise Bay. Segi (1956) and Segr \& Goto (1956, 1960) studied the development in nature of $M$. nitidum and $M$. latissimum at the culture ground in Ise Bay and obtained the same results as ArASAKI (1946, 1949).

Suneson (1947) reported that the zygote of $M$. grevillei became a unicellular 
cyst, although the further development of the cyst was not observed. As regards the life-history of M. grevillei, Kornmann (1962) and Kornmann \& Sahling (1962) investigated it in detail and reported that the cyst derived from the zygote discharged 4-flagellate zoospores which afterwards developed into leafy thalli.

On the other hand, the results differing from KunIEDA's were reported in several species of Monostroma. Working on M. pulchrum FARLOw from the vicinity of Muroran, YAMADA \& SaITo (1938) reported that the 4-flagellate zoospores discharged from the thalli became cysts, and the cysts discharged 4-flagellate zoospores again. TokidA (1954) was of opinion that the plant described by YAMADA \& SarTo as $M$. pulchrum was referrable to $M$. undulatum Wirtrock var. farlowii Foslie. Kornmann \& Sahling (1962), in consensus with TokIDA in regard to the identification, reported that their culture study of $M$. undulatum gave the same result as Yamada \& SAITo's.

YAMADA \& KANDA (1941) studied $M$. zostericola from Muroran and reported that the 4-flagellate zoospores discharged from the thalli developed directly into leafy thalli. In the same species, Yamada \& Tatewaki $(1959,196.5)$ clarified that the zoospores liberated from the leafy thalli (sporophytes) grew to form multicellular discs (gametophytes) from which the gametes were liberated and the zygotes grew into new leafy thalli.

According to Kornmann \& SAHLing (1962) who have studied $M$. arcticum and $M$. leptodermum from Helgoland, the former species repeated the leafy phase through 2-flagellate swarmers in its life-cycle while the latter produced always 4-flagellate zoospores which germinated into leafy thalli at such a low temperature as $3-4^{\circ} \mathrm{C}$. but the zoospores grew into prostrate filaments at a higher temperature as high as $15^{\circ} \mathrm{C}$.

Tatewaki (1963) discovered that $M$. fuscum var. splendens repeated the isomorphic alternation of leafy generations in its life-history.

Iшамото (1960) described a new species, $M$. tubiform, from Tokyo Bay, and reported that it discharged only 2-flagellate swarmers which developed directly into the masses of few cells. However, KIDA (1964) stated that this species agreed well with $M$. wittrockii from Ise Bay in its developmental mode.

Arasaki \& ToKuda (1961) revealed an important fact in $M$. wittrockii from Tokyo Bay that both zygotes and parthenogametes mostly grew into a single-celled stage, but in rare cases, especially in Aprile and May, a few zygotes and gametes developed on germination by successive cell-divisions into leafy many-celled thalli.

As regards the life-history of the Ulvaceae, it has been known that most species showed an isomorphic alternation of macroscopic generations. In the genus Ulva, Scinller (1907) reported that Ulva lactuca had three kinds of gametes, namely, (1) macrogamete, the largest, which has no ability of both conjugation and parthenogenesis, (2) parthenogamete, the medium sized, which has the ability of parthenogensis but not of conjugation, (3) microgamete, the smallest, which has the ability of isogamous conjugation. CARTER (1926) reported in her cytological study of 
the same species that the number of chromosomes was about ten and the zoospores had four flagella. Föyn (1929) confirmed in the same species that it had an isomorphic alternation of leafy generations and that the number of chromosomes was 26 in the sporophyte and 13 in the gametophyte. Mryake \& Kunieda (1931) studied the development of Ulva sp. from Misaki, which was closely resembling $U$. lactuca, and found that the zoospores had two flagella instead of four, unlike those of $U$. lactuca described by Schiller (1907) and by Föyn (1929). Tokida (1937) reported that $U$. pertusa from Hakodate produced three kinds of swarmers, namely anisogamous male and female gametes and 4-flagcllate zoospores, and he traced the development of the zoospores. In $U$. pertusa from Muroran, Yamada \& Saito (1938) observed the development of the zygotes derived from the isogametes and that of the 4-flagellate zoospores and the parthenogametes, and clarified that both zygotes and zoospores developed into a simple filaments by transverse ccll-divisions, and those filaments grew by longitudinal cell-divisions into young Ulva plants consisting of two layers of cells. Möwus (1938) distinguished three races of $U$. lactuca, one from Helgoland, the second from Naples, and the third was the same material as cultured by FöYN. The race from Naples was anisogamous, while other two races were isogamous, and the thallus derived from the zygote discharged 4-flagellate zoospores which developed into gametophytes. Moreover, he proved by culture experiments that the size of the gametes was hereditary in each of the three races.

ArASAKI (1946) reported his investigation on the swarmers and their development in Ulva from Ise and Mikawa Bay. He stated that the number of flagella in $U$. lactuca was two as observed by Mryake \& Kunieda (1939) and it was four in $U$. pertusa as reported by Tokida (1937) and Yamada \& SaIto (1938).

As a result of his studies on the reproduction of Ulva from Monterey Peninsula, California, Smrth (1947) reported that the sexual reporduction was anisogamous in $U$. lobata, $U$. angusta and $U$. stenophylla, while it was isogamous in $U$. taeniata. He investigated at the same time the periodicity of reproduction of these species.

Studying the life-cycle of $U$. conglobata from Misaki, FujIYama (1950) reported that this species produced both male and female gametes and 2-flagellate zoospores, and that both zygotes and zoospores developed into leafy thalli as in other species of Ulva.

BLiding (1960) reported that $U$. neapoletana Bliding from Naples never showed alternation of generations and its swarmers were always asexual 2-flagellate zoospores.

Working on the life-history of Ulva (Letterstedtia) japonica from Shimoda, Chimara (1953) reported that the plant was dioecious and isogamous, the zoospores were 4flagellate, and that the development of this species closely resembled that of $U$. pertusa. In her studies on Letterstedtia insignis from Salt Vlei and Waterloo Bay in South Africa, Pocock (1959) obtained a result which is quite similar to the cycle of Ulva.

In the genus Enteromorpha, the reproduction was studied by many investigators 
since Thurer (1850) who observed the conjugation of 2-flagellate gametes in $E$. clathrata. The development of the sporeling in its early stage was observed by KYLIN (1930) in E. intestinalis, and by Mryake \& KunIEDA (1931) in Enteromorpha sp. Bliding (1933) studied five species of Enteromorpha, i.e., E. linza, E. clathrata, E. prolifera, $E$. compressa and $E$. procera, collected in the vicinity of the Zoological Station at Kristineberg in Sweden, and confirmed by culture experiments that the zygotes, parthenogametes and zoospores developed into a simple filament at first and later became a sporeling consisting of compound rows of cells, and eventually grew into a tubular thallus. He also researched the reproduction and life-history of these Enteromorphas and proved that $E$. linza produced always 4-flagellate zoospores and the thalli derived from the zoospores discharged 4-flagellate zoospores again. YamadA \& SAITO (1938), working on E. linza from Muroran, obtained a similar result as BLIDING's, but they observed sometimes also 2-flagellate swarmers which did not conjugate with each other.

In his studies on E. intestinalis, E. compressa, E. linza and E. lingulata, Möwus (1938) was successful in repeating the entire life-cycle of these species in culture experiments, and he analyzed the generations derived from the zygotes, zoospores, and from parthenogametes. The thalli derived from 2-flagellate parthenogametes in $E$. intesitinalis and E. compressa, discharged 4-flagellate zoospores, and those zoospores developed into the thalli which discharged 4-flagellate zoospores again. MöwUs interpreted these phenomena to the effect that the parthenogametes became diploid at the first stage of their development and then grew into the sporophytes which produced diploid planogonidia without reduction division. $\mathrm{He}$ also reported that there were two races in E. linza of which the one collected in Helgoland was dioecious and had a regular isomorphic alternation of generations while the other from Sweden produced always zoospores which partly developed into gametophytes when placed in a culture solution for Volvox. E. lingulata from Naples was revealed by him to be monoecious.

Bliding (1939) compared the morphological structures among several types of $E$. prolifera and among those of $E$. linza and proved the ability of conjugation between two different types in either of the species. He published $(1948,1955,1960)$ the results of his studies on the classification and life-history of several species of Enteromorpha such a; E. kylinii Bliding, E. intermedia Bliding, E. jugoslavica Bliding, E. multiramosa Bliding and $E$. stipitata P. Dangeard var. linzoides Bliding.

Working on the Ulvaceous plants from Ise and Mikawa Bay, AraSAKI (1946) stated that the algae belonging to this family could be classified into the following four types according to the early developmental stages of the thallus: (1) Ulva-E. linza type (the sporeling attaches to substratum by rhizoids from the beginning of its development; to this type belong $U$. lactuca, $U$. pertusa, $E$. linza, $E$. intestinalis, $E$. prolifere and $E$. compressa); (2) E. bulbosa zoospore type (the spore develops into a protonema-like creeping thallus). (3) E. nana type (the spore grows into a disc). 
(4) E. fasia type (the spore develops into an elongate thallus of various shapes, either flexious or constricted, attaching to substratum by either a few-celled filamentous or discoid attachment). E. linza was reported by ARASAKI to be represented by both gametophytic and sporophytic individuals in his specimens from Ise and Mikawa Bay, and the same was also reported by TокIDA (1954) in his specimens from Saghalien, but the latter author's material from Hakodate produced 4-flagellate swarmers only during the period of his observation from March to November. Arasaki and Shinira (1959) studied this species collected in all seasons at several places near Tokyo and clarified that the mode of reproduction and the shape of thallus were quite variable from place to place and from season to season, and that this species could be separated into two types according to the mode of reproduction: the principal method of reproduction was sexual in one of them while it was asexual in the other.

Dangeard $(1957,1959,1960,1961)$ studied the thallus development of Enteromorpha species, such as E. stipitata and E. gayralii from Morocco, and E. sancti joannis DANGEARD and E. kylinii from France.

BuIDING's report (1938) on the development of E. minima is as follows. The germinating zoospores sends out a tube, into which the spore contents migrate and the distal end of the tube becomes a new cell which later develops into a disc by repeated cell-divisions. Then the central part of the disc begins to upheave and develops eventually into a tubular thallus. Investigating this species, KyLIN (1947) obtained the same result as BLIDING's and established a new genus Blidingia on the basis of this species which is so unique in the type of development to be retained in the genus Enteromorpha. A similar type of development was reported by Yamada \& KANDA (1949) in E. nana var. minima from Muroran, by ARASAKI (1946) in E. nana from Ise and Mikawa Bay, by Dangeard (1958) in E. marginata from France, and by Iwamoto (1960) in E. marginata from Tokyo Bay.

In the genus Capsosiphon, BLIDING (1935) studied the development of $C$. aureolum from Sweden which was later regarded by him as a synonym of $C$. fulvescens. He reported that the swarmers of this alga were 4-flagella $\cdot e$ zoospores and developed usually into uniseriate thalli. Iwamoto (1959) observed some specimens of $C$. fulvescens collected from a culure-net of Porphyra in Tokyo Bay and assumed that the 2-flagellate swarmers produced from them were gametes.

In the genus Percursaria, Kornmann (1956) studied the morphology and lifehistory of Percursaria percursa from Helgoland, and reported that the sexual plant produced 2-flagellate garnetes from dioecious thalli while the asexual 4-flagellate zoospores, and that they developed into filamentous or disc-like sporelings which grew into bi-seriate thalli. Moreover, he could observe that this species repeated several generations in culture, and that the following three cases existed in the development of non-conjugable gametes: (1) all gametes grew into gametophytes, (2) all gametes grew into sporophytes which were assumed to be haploid, and (3) some gametes grew into gametophytes while the others into sporophytes, 
Studying the European taxa of Ulvales, Buming (1963) enumerated six genera in the family Ulvaceae and described one species in Capsosiphon, one species in Percrusaria, three species, two subspecies and one variety in Blidingia and seventeen species, eight subspecies and six varieties in Enteromorpha. The genus Enteromorpha was divided into seven groups, namely Torta, Prolifera, Jugoslavica, Flexuosa, Clathrată, Linza and Intestinalis. BLiding has left Ulva and Ulvaria of the Ulvaceae as well as the Monostromaceae to be treated in the future.

Chinara (1958, 1959, 1960, 1962) studied the life-history of three species of Collinsiella, i.e., C. tuberculata, C. cava and C. japonica, from Izu Peninsula, and reported that (1) the life-history of C. cava was quite similar to that of some Monostroma in having alternation of generations between thick-walled unicellular cyst and macroscopic multicellular gametophyte, (2) the zoospore, on germination, grew at first into a disc just like in certain Monostroma species such as $M$. angicava, and (3) there was no essential difference Collinsiella cava and Monostroma sp. in the growing manner of cysts which, penetrating into calcareous substrata, had a resemblance to the "sporangium" of the genus Gomontia.

On the other hand, Scagel (1960) carried out culture experiments and field observations of Collinsiella tuberculata from Canada, and reported that a small globose thallus (Collinsiella stage) produced 2-flagellate gametes which conjugated in pairs and the zygotes grew into Enteromorpha-like plants (Enteromorpha stage), and also that 4-flagellate zoospores derived from $E$. intestinalis developed into sporelings which agreed well with the Enteromorpha-stage obtained from Collinsiella-stage. Moreover, he observed the gametophytes and sporophytes of $E$. intestinalis of typical form in the field. Therefore, he stated that the Collinsiella-stage was no other than the basal remnant of the typical gametophytic plants of $E$. intestinalis. Comparing these results with the aforesaid life-history of Collinsiella cava reported by CHIHARA, Scagel stated, "The conclusions to be drawn from these observations would further support the need for recognizing a single family, the Ulvaceae, to include not only Ulva, Enteromorpha and related genera, but also Monostroma and Blidingia". Scagel's view on the Collinsiella-stage of Enteromorpha is cited in the latest textbooks written by BONEY (1966) and by DAwson (1966).

As regards the interrelation between Monostroma and Gomontia, Arasaki \& TokUda (1961) reported that the zygotes and parthenogametes of a species of Monostroma which might be referable to $M$. grevillei or $M$. angicava, grew always, when placed on Mollusc shells, into single-celled Gomontia-like bodies which later penetrated into the shells. They also discovered in the field that many Gomontia thalli were present in the shell fragments from a place where Monostroma was growing. In the laboratory these authors could observe that small young thalli of Monostroma were found growing in a glass vessel filled with sea-water in which the shells with Gomontia had been kept. As a result, they suggested that this Gomontia in the shells was the unicellular stage of Monostroma, and that the shell-boring character of the germlings might be a key to 
solve a puzzle in connection with the life-history and classification of Monostroma species.

KorNMANN $(1963,1965)$ is of opinion that the Monostromaceae should be placed in the order Ulotrichales since that order is characterized by the possession of the unicellular cyst-like generation or "Codiolum-Stadium", and that some members of the Monostromaceae such as $M$. leptodermum and $M$. fuscum which are lacking "Codiolum-Stadium" should be transferred to the Ulvales, while the Monostromaceae should include Gomontia and Collinsiella besides Monostroma.

From the above brief review it is known that there still remains some problems concerning the systematic relationships of certain species and genera. Since 1952 I have engaged in researches on the life-history of several genera belonging to the Monostromaceae and Ulvaceae, from 1952-1953 at the Institute of Algological Research, Muroran, and from 1962-1966 at the Suma Aquarium, Kobe. Up to the present I could trace the entire or partial life-history of fifteen species and published a part of the results $(1964,1965,1966)$. In the present thesis I will describe all of the results and give a discussion on them.

\section{Acknowledgement}

Here I wish to express my deepest gratitude to Professor Emeritus Jun Tokida of Hokkaido University for his helpful advices and suggestions, and to Professor Hiroyuki Hirose of Kobe University for his kind guidance and for taking trouble in revising the manuscript. My thanks are also due to Mr. KineijI Inoue, director of Suma Aquarium, for his valuable suggestions, to Professor Emeritus Yukio Yamada of Hokkaido University under whose guidance I studied the development of three species of Monostroma at Muroran, to Professor Yoshiteru Nakamura of Hokkaido University for his valuable advices given during my stay at the Institute of Algological Research of Hokkaido University, to Professor Emeritus SABuro UEda of Tokyo University of Fisheries for his kind guidance while I was studing Enteromorpha and Monostroma at his laboratory, to Professor SEIBIN ARASAKI of Tokyo University for his valuable suggestions, and to Dr. Masaru Akiyama of Shimane University for his helpful advices. I am also indebted to the kindness of Dr. TAKasI TokiokA, Professor Huzio Utinomi, and Mr. Chuichi Araga of Seto Marine Biological Laboratory of Kyoto University at Shirahama in giving me many facilities when I stayed at the laboratory; to Mr. ToRao Yамамото of the same laboratory for his kind helps in collecting the materials at Shirahama. I acknowledge my indebtedness to $\mathrm{Mr}$. Sachito Enomoto and Mr. Shigeru Kumano of Kobe University for their kind assistance and valuable advices. Finally I wish to offer my thanks to my colleagues at the Suma Aquarium, especially to Dr. Ryonosuke Okuno, and Messrs. Kazuhiko Harashima, Motonki Shiomi, Tatsuo Inaba, Masao Nishiguchi, Tetsuo Kurio and Hiroshi Aмmoтo, who helped me in many ways, especially in bringing valuable materiales to Kobe. 


\section{Addenda}

After the manuscript of the present thesis had been completed in 1966, several significant papers were published by several authors.

As regards the Monostromaceae, KIDA (1966) reported the morphology and ecology of $M$. latissimum and $M$. wittrockii from Ise Bay and its vicinity. TokudA \& Arasaki (1967) discussed the interrelation between Monostroma and the Codiolumphase or Gomontia-like stage in their previous paper (1961). Recently TATEwaKI (1969) investigated the life-history of six species of Monostroma, and reported as follows: (1) the structure and development of the frond are divided into two types, (2) the mode of swarmer-liberation is summarized as having two types, (3) all sp cies examined are different among one another in their respective life-histories, and (4) the genus Monostroma is demonstrated to include six haterogenous groups, namely, groenlandicum-, undulatum-, oxyspermum-, angicava-, zostericola-, and fuscum-group.

In the genus Capsosiphon, Chimara (1967) studied C. fulvescens from the Izu Peninsula and reported that the alga was dioecious and its zygote developed into a new thallus identical with its parents. On the other hand, Mrgita (1967) clarified in the same species from Nagasaki that the zygote developed into a unicellular cyst which produced zoospores and the zoospore grew into a multicellular thallus.

BuIDing (1968) described eight species of Ulva in his "A critical survey of European taxa in Ulvales, II" and also transferred several members of Monostroma with alternation of isomorphic generations to the genus Ulvaria in the Ulvaceae. He described only three species under the genus Monostroma and referred $M$. leptodermum and $M$. zostericola to a new genus, Kornmannia, placed preliminarily in Monostromaceae together with Blidingia. Besides, he removed the genera Capsosiphon and Percursaria from Ulvaceae, and placed the former in Capsosiphonaceae CHAPMAN and established a new family, Percursariaceae, for the latter.

\section{MATERIALS AND METHODS}

The species treated in the present thesis and the collecting stations of them are shown in Table 2.

The materials collected were mostly growing on rocky shores, on stones in sandy beaches, on stakes and quays in the intertidal zone. Enteromorpha ramulosa was found interwoven around the floating matters, and $E$. compressa was growing in a big elliptical show-tank, $19 \mathrm{~m}$ long by $7 \mathrm{~m}$ wide and $2.7 \mathrm{~m}$ deep, at the Suma Aquarium.

Studies on Monostroma undulatum, $M$. angicava and $M$. zostericola were carried out from 1952 to 1953 at the Institute of Algological Research of Hokkaido University, while other species were investigated from 1962 to 1966, mainly at the Suma Aquarium, Kobe, but partly either at the Institute of Biology, Faculty of Science, Kobe University, or at the Seto Marine Biological Laboratory of Kyoto University. In the last mentioned case, the fertile thalli were collected at Shirahama beach and the swarm- 
Table 2. Species and collecting station

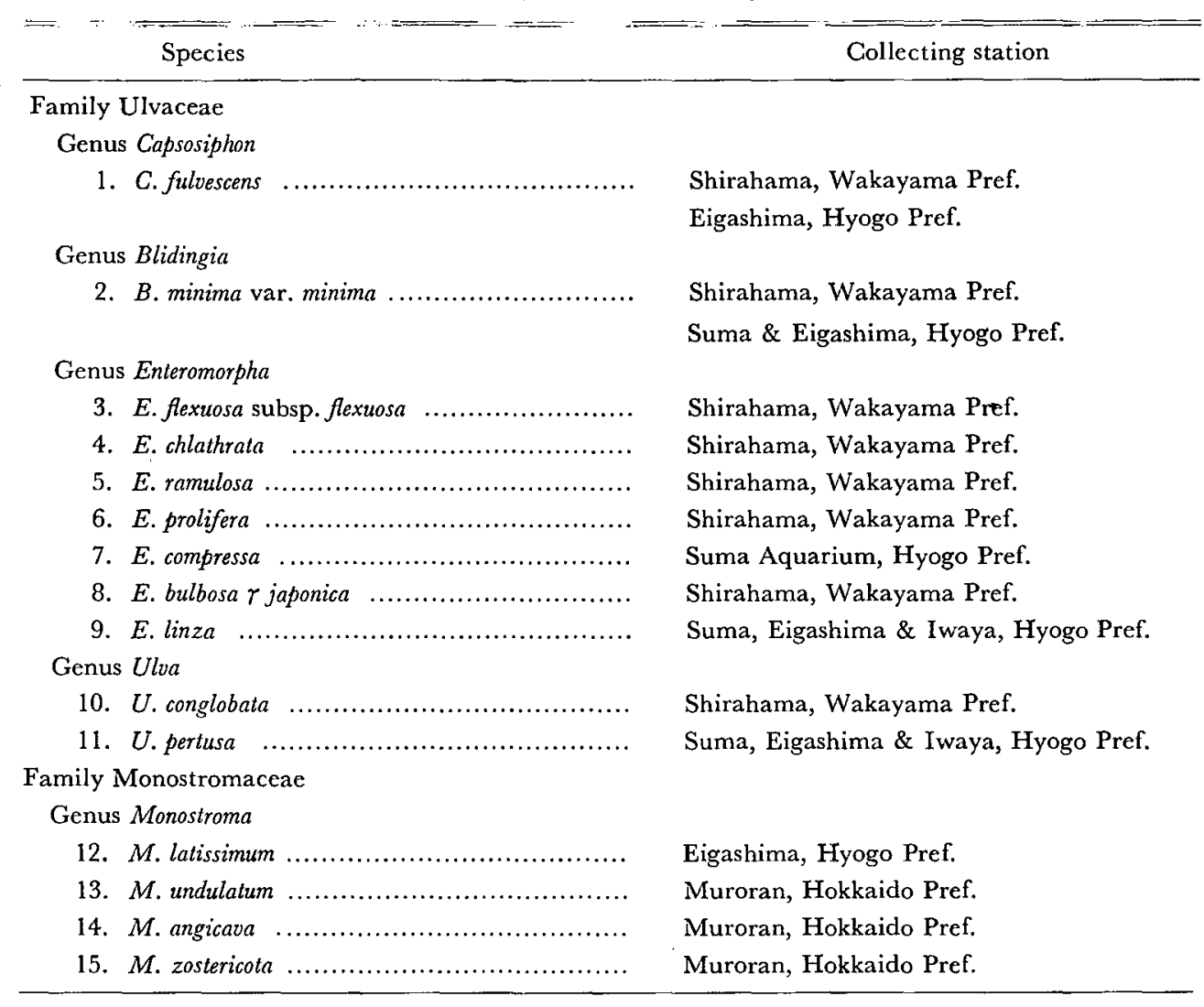

crs leberated from them were attached to slides. These slides were put in a thermos and brought to the laboratory at the Suma Aquarium. For the liberation of swarmers, the fertile parts were cut off from the mature thalli in the field, rinsed carefully with filtered sea-water, and then put into glass-vessels filled with filtered sea-water. Liberation of swarmers from these fertile parts took place soon.

Dimentions of 20-30 swarmers were measured and their mean value was obtained for each species. Copulation between swarmers was tested under microscope by mixing on a slide a pair of drops each containing the swarmers discharged from their respective mother thallus. The swarmers and zygotes attached to the slides soon germinated to develop into germlings which were cultured in a glass-vessel containing 200-300 $\mathrm{ml}$ of the medium. At Muroran, the vessels were placed in a culture room kept at a lower, not controlled, temperature and they were not exposed to direct sunlight. At the Suma Aquarium, the vessels were placed near the west windows of the laboratory and exposed to 3000-8000 lux in the daytime. The temperature of the culture medium in the vessels and in the big show-tank is shown in Fig. 1. In the culture of Blidingia minima, E. flexuosa, E. clathrata, E. prolifera, E. bulbosa and 
Ulva conglobata, the temperature of the medium was partly controlled to be kept at $15-18^{\circ} \mathrm{C}$. In order to know the relation between germling development and direction of light, the culture vessels were fully painted black outside leaving a narrow rectangular window through which the light went into the vessel and falled either on the surface of the slanted slide bearing the attached swarmers or on the side of the horizontal slide laid on the bottom of the vessel.

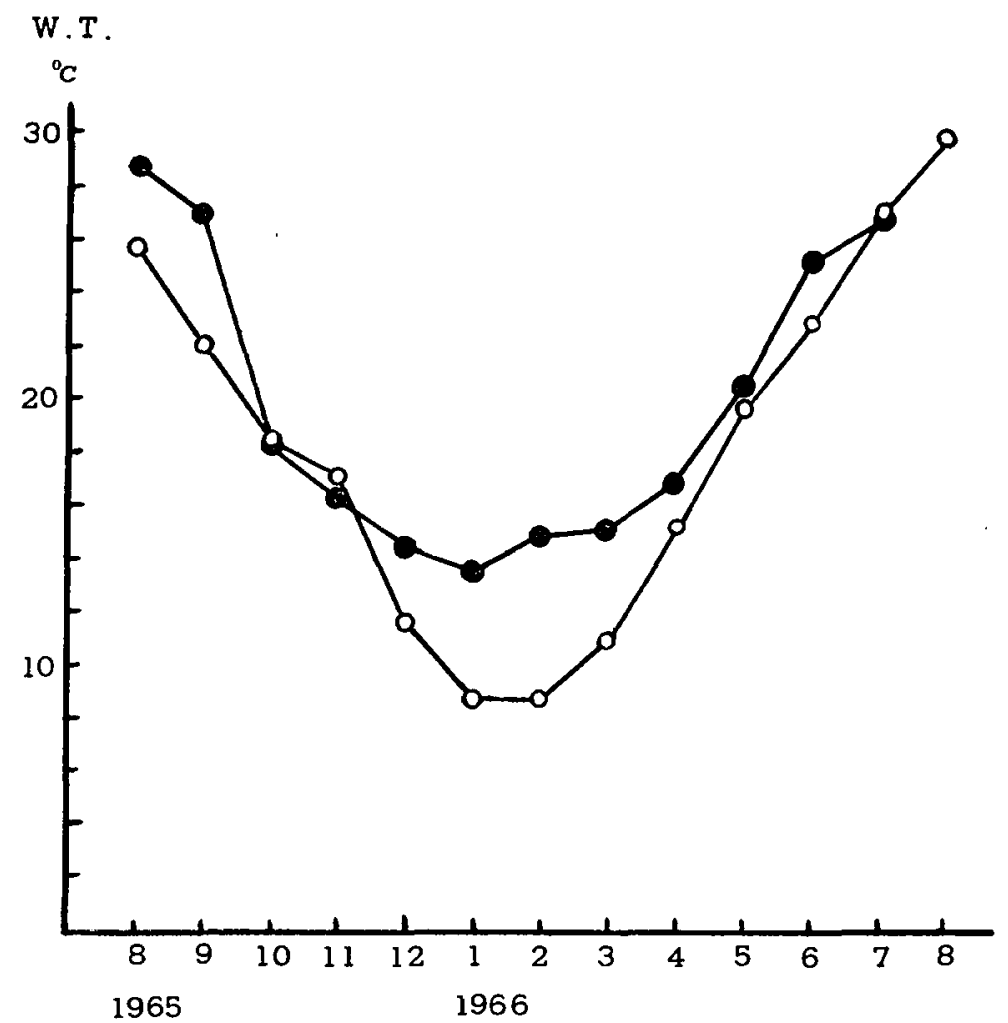

Fig. 1. Water temperatures of culture medium in the vessels (solid circle) and in the big show-tank at the Suma Aquarium (open circle), monthly average during the period from August 1965 to August 1966.

The culture medium employed in former experiments was Schreiber solution. Since 1964 Provasoli's ES medium has been used for my cultures and the sporelings were found to grow better in this latter medium. After the sporelings had developed into a stage visible to the naked eye, $\mathrm{CO}_{2}$ gas was blown into the medium twice a day by exhaling through a pipe. 


\section{RESULTS}

\section{Family Ulvaceae}

\section{A. Genus Capsosiphon GoBI 1879}

Thallus is simple, filamentous, cylindrical and polysiphonous in upper portions but often monosiphonous in lower portions.

The cells in surface view are arranged in longitudinal or oblique series which are loosely joined together. The cells are often grouped in twos or fours as in many species of Monostroma.

It was confirmed in the present study that Capsosiphon fulvescens is dioecious and its 2-flagellate isogametes conjugated with each other. BLIDING (1935, 1963) reported that his Swedish specimens repeated sporophytic generations by producing 4-flagellate swarmers and rarely also 2-flagellate swarmers of uncertain nature.

The germlings derived from the zygotes and parthenogametes were observed to be commonly of the typical nature of the genus, but rarely they consisted of several large cells or they remained undivided and grew to large cyst-like cells.

The gametes liberated from a gametangium of $C$. fulvescen; in my culture are enclosed in a hyaline mucilage sac. In this mode of liberation the present genus resembles the genus Percursaria, a member of the Ulvaceae, and also the members of the Monostromaceze and Ulotrichaceae, but it differs from. Blidingia, Enteromorpha and Ulva.

The germlings attach to the substratum by rhizoids from the beginning of their development.

It should be noted here that the genus Capsosiphon may be excluded from Ulvaceae for the following reasons: (1) the cells in surface view of thallus are often grouped in iwos or fours, (2) the gametes liberated from a gametangium are enclosed in a hyaline mucilage sac, and (3) thc zygote develops into a cyst-like cell.

\section{Capsosiphon fulvescens (C. AGRDH) Setchell et GARDNER}

\section{Japanese name: Kapusa-aonori (TokidA)}

Setchell \& Gardner, 1920, p. 234; Collins, 1928, p. 126 (as Ilea fulvescens) ; Bliding, 1935, p. 62; 1963, p. 15; ToKida, 1942, p. 82; Kylin, 1949, p. 16; Iwamoto, 1959, p. 7.

Adult plants are growing densely on stones, stakes, quays or on the culture-net of Porphyra, in the littoral zone or sometimes even above the high water mark, so that they are exposed even in the smallest change of tide and dried up entirely in the largest (Fig. 2. C). I investigated this alga collected at Eigashima from 1964 to 1966. It grows there from late-December through mid-May, especially luxuriantly in the period ranging between January and March. A culture experiment was also carried out with the material collected at Tsunashirazu of Shirahama in February 
K. Yoshida

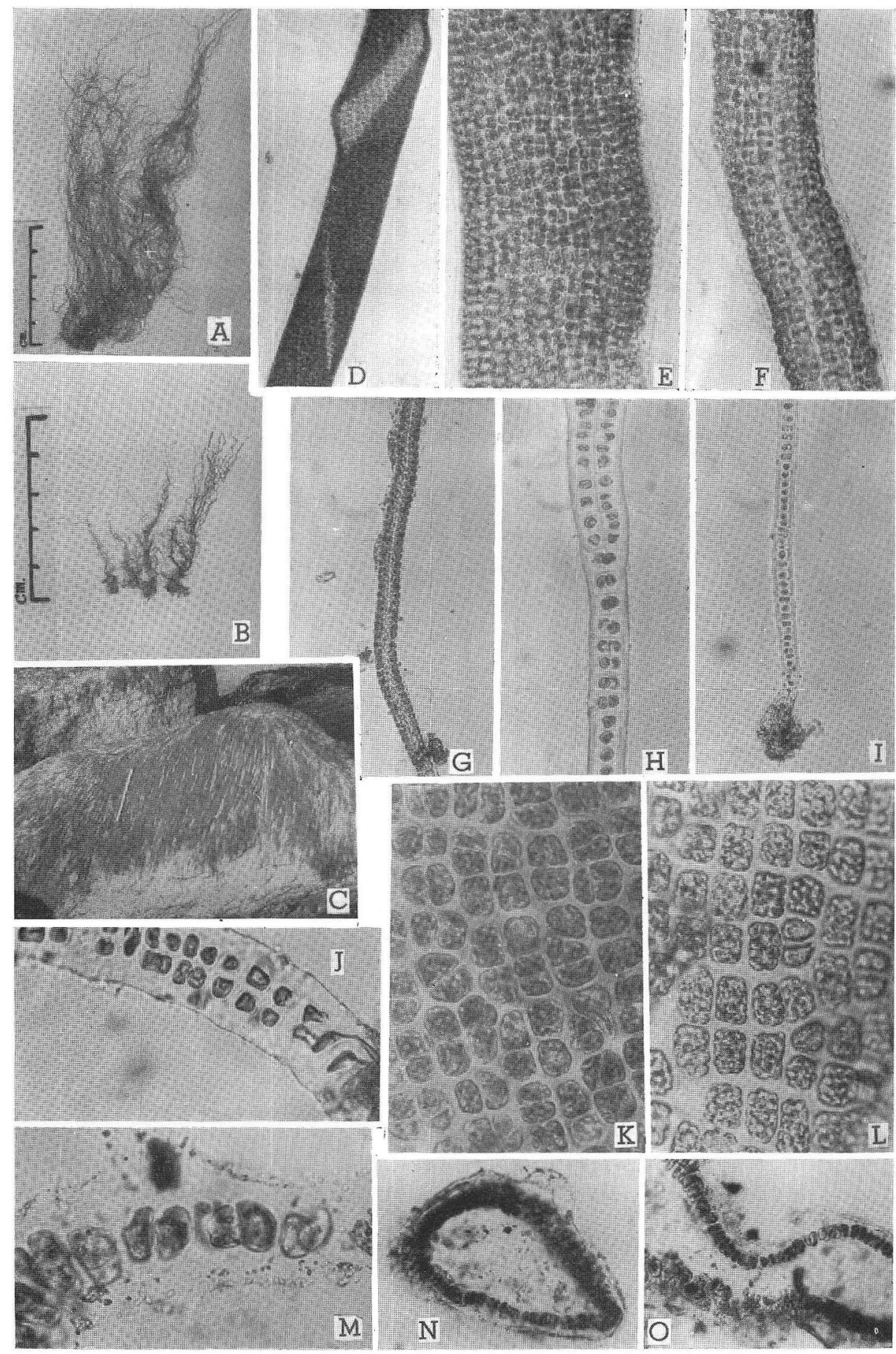

Fig. 2. Capsosiphon fulvescens. A: tufts of thalli from Eigashima. B: tufts of thalli from Shirahama. C: habit of the plant growing on a stone in the littoral zone exposed during low 
and March, 1966. The fertile thallus is simple, filamentous, $3-13 \mathrm{~cm}$ in length, $0.3-0.5 \mathrm{~mm}$ in breadth, dark green to brownish-green in colour (Fig. 2. A, B), cylindrical, hollow or often filled with intercellular substances. Many splits are seen here and there on the surface of the tubular body (Fig. 2. F). In a surface view, the cells are grouped in twos or fours, and arranged in longitudinal, often spiral, series loosely joined together, so that the thallus easily splits obliquely when pressed under a cover glass (Fig. 2. D, E, K). The lower most part of thallus is often monosiphonous in structure (Fig. 2. H, I) and passes upwards into a part composed of cells seriated in a few rows. In such a part, 2-4 cells are often enclosed within the wall of a mother cell (Fig. 2. H). The specimens growing on stones buried in mud have a thallus with a longer basal part. Each cell contains a parietal chloroplast and one pyrenoid. The thallus attaches to the substratum by rhizoids (Fig. 2. J).

In a surface view, the cells are roundish rectangular or quadrangular, 8-10X $8-13 \mu$ in the middle part of thallus and $12-18 \times 20-22 \mu$ in the upper part (Fig. 2. K). In a sectional view, the cells are roundish quadrangular or ovoid, 15-17 $\mu$ high, and the cell membrane is $35-45 \mu$ in thickness (Fig. 2. M-O).

The cells in my specimens are of similar size as those described by TokIDA (1942) and Bliding (1963) but they are larger than those observed Setchell and Gardner (1920) and Collins (1928).

Reproduction and development: The reproductive cells of the present species are formed in the upper part of the thallus. The fertile part of thallus becomes loose in cell arrangement (Fig. 2. L). I could confirm that this species is dioecious and the male and female gametes conjugate with each other. Formation of asexual zoospores was not observed. The germlings developed from the parthenogametes sometimes consisted of several large cells (Fig. 3. E, F). Iwamoto (1959) observed "akinate-like spores" within the gelatinized cell-membrane of this species from Tokyo Bay. He also described the 2-flagellate swarmers and interpreted that they might be gametes. Bliding (1935, 1963) reported that the swarmers of this species from Sweden were usually 4-flagellate and asexual, and that the materials from Fiskebäckskil near Kristineberg (in brackish and polluted water) produced both 4-flagellate large swarmers and 2-flagellate small ones.

In the material either collected in the field or raised in the culture, the gametes discharged from the gametangium were always observed to be enclosed in a hyaline mucilaginous sac. Such an aggregation of swarmers soon collapsed and the swarmers dispersed in a few seconds after discharge from the sporangium (Fig. 3. A, B). Such

tide, at Eigashima. D: part of adult thallus pressed and split obliquely under a coverglass. E: middle part of thallus showing arrangement of cells. F; part of thallus with a split. G: lower part of thallus. H: basal part of thallus showing cells in twos or fours enclosed within walls. I : basal part of thallus composed of uniseriate cells. J : basal part of thallus showing rhizoids. $\mathrm{K}$ : surface view of the middle part of thallus. $\mathrm{L}$ : fertile part of thallus showing gametangia. M-O : cross-section of the thallus, showing upper $(\mathrm{M}, \mathrm{O})$ and lower $(\mathrm{N})$ portions. $\mathrm{D} \times 50, \mathrm{E}-\mathrm{G}, \mathrm{I}, \mathrm{N}-\mathrm{O} \times 125, \mathrm{H}, \mathrm{J} \times 300, \mathrm{~K}-\mathrm{M} \times 450$. 

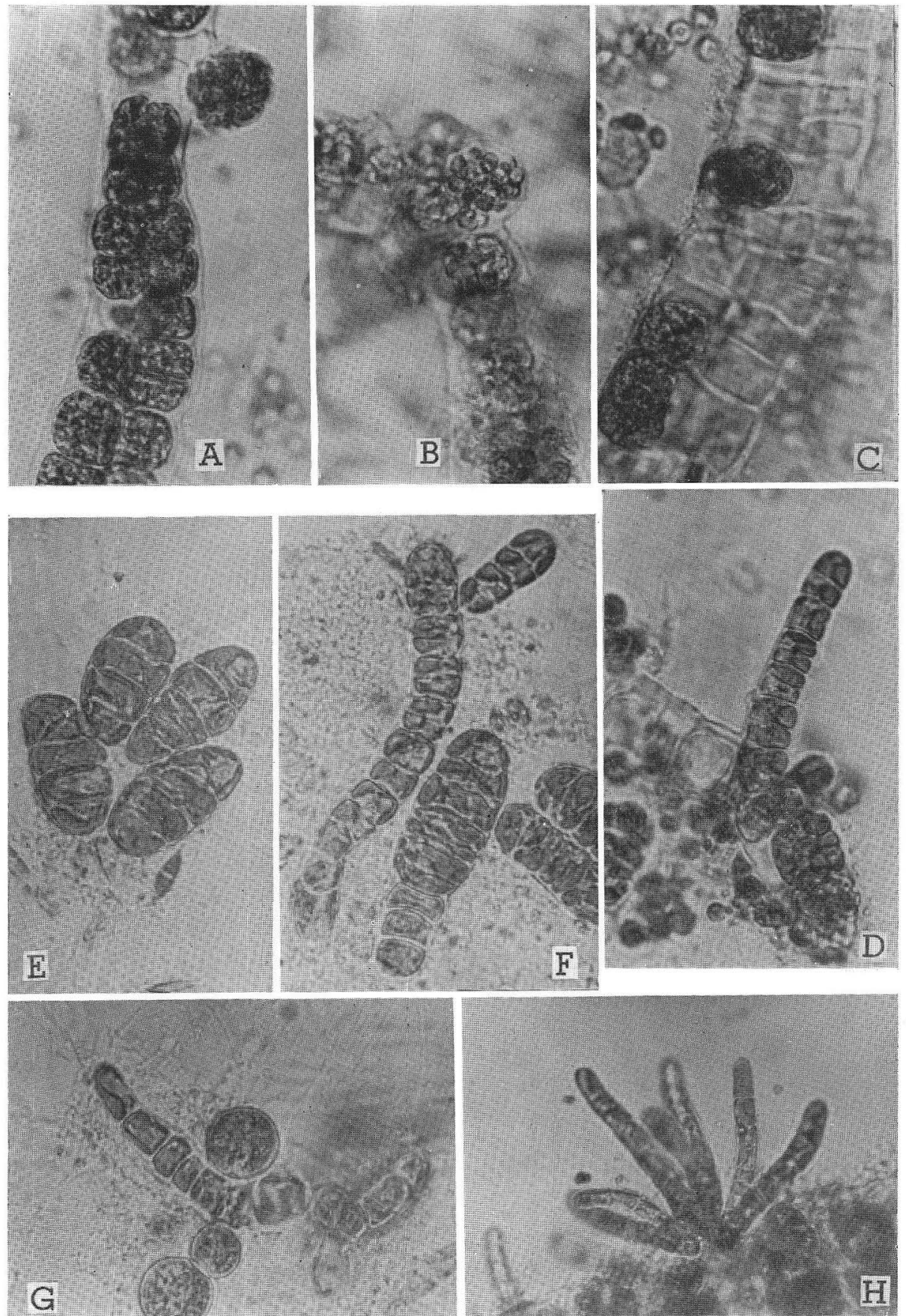

Fig. 3. Capsosiphon fulvescens. A-B : discharge of swarmers enclosed in a hyaline mucilagenous sac. C: part of fertile thallus showing gametangia before and after liberation of gametes. D: germling attached to fertile thallus. E-G: germlings and cyst-like cells observed within the gelatinized membrane of the gametangia after liberation of the gametes. E-F : germlings consisting of several large cells. G: cyst-like cells and a filamentous germling. H: germlings growing in a cluster on fertile thallus. A-D $\times 630, \mathrm{E}-\mathrm{G} \times 550, \mathrm{H} \times 400$. 
was also reported by BuIDing (1963) in the European materials of this species.

There is no clear difference in size between the male and female gametes. They are $3.3 \times 8.1 \mu$ on an average and are furnished with a distinct eyespot (Fig. 4. A).

As soon as discharged from the gametangium, the gametes begin vibration within a hyaline mucilaginous sac and in a few seconds they swim out of it explosively. Then they gather to the surface of water at the brightest side of the vessel. Soon after the conjugation of the gametes, the planozygotes gather to the bottom of the vessel at its darkest place (Fig. 4. B). The zygotes soon become motionless and roundish in shape, and fasten to the substratum. The zygotes and the parthenogametes developed in culture into adult plants. Cultures of the materials from Eigashima $\left(12-14^{\circ} \mathrm{C}\right)$ and of those from Shirahama $\left(13-17^{\circ} \mathrm{C}\right)$ were started on the 12 th February 1966 and on the 16th March 1966 respectively. The cells fastened to the

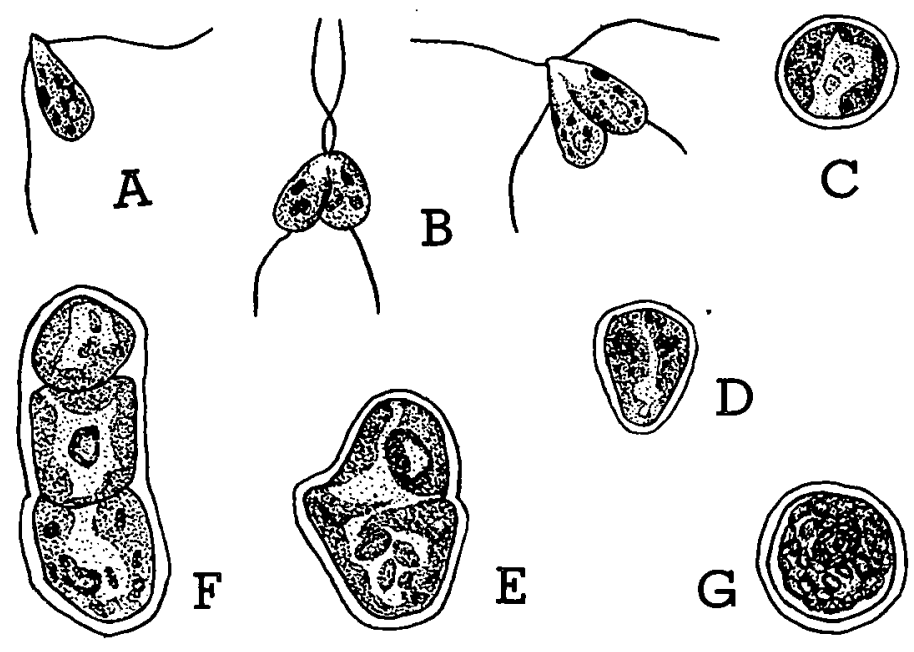

Fig. 4. Capsosiphon fulvescens. A: gametes. B: copulation of isogamous gametes. C: 5-day-old zygote. D: zygote in its initial stage of germination. E-F : germlings at early stages of development. G : cyst-like cell, ca. two-week-old. A-G $\times 1500$.

substratum began to elongate after three days and then divided into two cells (Fig. 4. $\mathrm{D}, \mathrm{E})$. In one week, the germling grew to a 5 or 6 -celled simple filament attaching to the substratum by a basal rhizoid cell (Fig. 5. A, B). The days after the start of the culture, the germlings developed into monosiphonous filaments consisting of 14 to to 22 cells (Fig. 5. C-E). After about one month, the germlings developed from the Shirahama material were $300-900 \mu$ in height and some of them consisted of two to several seriate cells in the middle and basal parts of the thallus (Fig. 5. F-J). Sometimes they were still uniseriate even after grown to a 75-80-celled stage. The rhizoids at this stage of germling growth were very poorly developed yet (Fig. 5. F). In the material from Eigashima, the germlings reached $800-1100 \mu$ in height after 
K. YoshidA

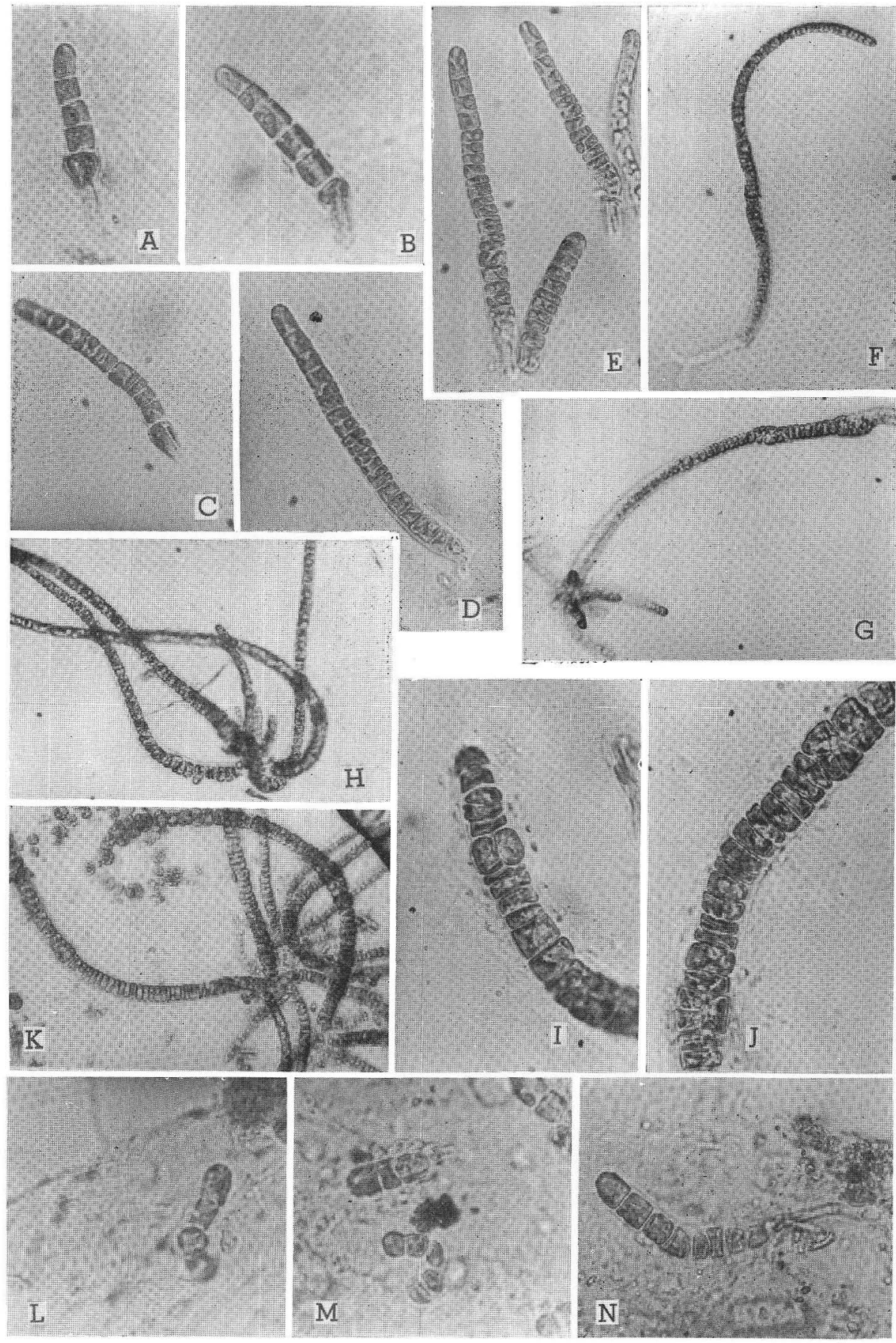

Fig. 5. Capsosiphon fulvescens. A-J : germlings obtained by culture, one-week-old (A, B), 10day-old (C-E), ca. one-month-old (F-J) germlings. F: germling fastened to substratum by a rhizoid bearing irregular projections. $\mathrm{G}$ : germling which has become multiseriate in the 
about one month since the start of culture. They were monosiphonous in the upper and lower parts of the thallus but composed of two to several seriate cells in the middle part (Fig. 5. I, J). At this stage, liberation of the swarmers was observed (Fig. 5. K). Most of the swarmers showed a positive phototaxis. It was not confirmed whether these swarmers were of sexual or asexual nature.

The above described feature in the early developmental process of the germlings attached to the slide was also observed in the germlings developed from the swarmers which had germinated within their mother cells (Fig. 5. L-N).

The attaching organs of this species are rhizoids from the first step of the thallus growth, though BLIDING $(1935,1963)$ maintained that the holdfast of young germlings in this species had no rhizoidal cells but it consisted only of round cells.

I carried out cultural experiments with the material from Eigashima five times from 1964 to 1966 and with that from Shirahama two times in 1966. In every experiment it was found that cyst-like cells mixed with the zygote girmlings on the slides. Those cells were derived from the zygotes which increased their size without cell-division.

Soon after the zygote attached to the substratum it became roundish in shape, measuring 3-4.5 $\mu$ in diam., and surrounded by a membrane. After 5 days the zygotes became about $7 \mu$ in diam. (Fig. 4. C). Then they increased their size becoming up to $10-12 \mu$ in diam. (Fig. 4. G). At the same time the peripheral portion of their contents was filled with starch granules and the contents themselves turned to somewhat dark green, being surrounded with a thick membrane. After 40 days the cyst-like cells reached $30-34 \mu$ in diam. (Fig. $6 . \mathrm{H}$ ).

In the culture of the material from Shirahama, started on the 16th March 1966, several cyst-like cells derived from zygotes reached about $35 \mu$ diam. and formed many swarmers within them on the 15th April (Fig. 6. I). A few days later the swarmers were discharged from the cyst-like cells. Unfortunately I failed to clarify the feature and development of the swarmers.

Large cyst-like cells were also frequently observed within the gelatinized membrane of the gametangia after liberation of the tgametes (Fig. 3. G). It is thus possible to say that $C$. fulvescens has the unicellular cyst-like stage in its life-cycle.

\section{Addenda}

Recently several significant papers on $C$. fulvescens were published.

Chimara (1967) reported that C. fulvescens from the Izu Peninsula was dioecious

middle portion. $\mathrm{H}$ : germlings growing in a group. I-J : part of germlings showing longitudinal divisions in intercalary cells. $\mathrm{K}$ : germlings which are partly fertile already, are shown growing in groups. L-N: germlings observed within the gelatinized membrane of the gametangia after liberation of the gametes. L-M:3- or 4-cell stage of germlings. $N$ : 9-cell stage of germling with a long rhizoid. A-B, L-N $\times 450, \mathrm{C}-\mathrm{E} \times 300, \mathrm{~F}-\mathrm{G}, \mathrm{K} \times 150$, I-J $\times 500$. 


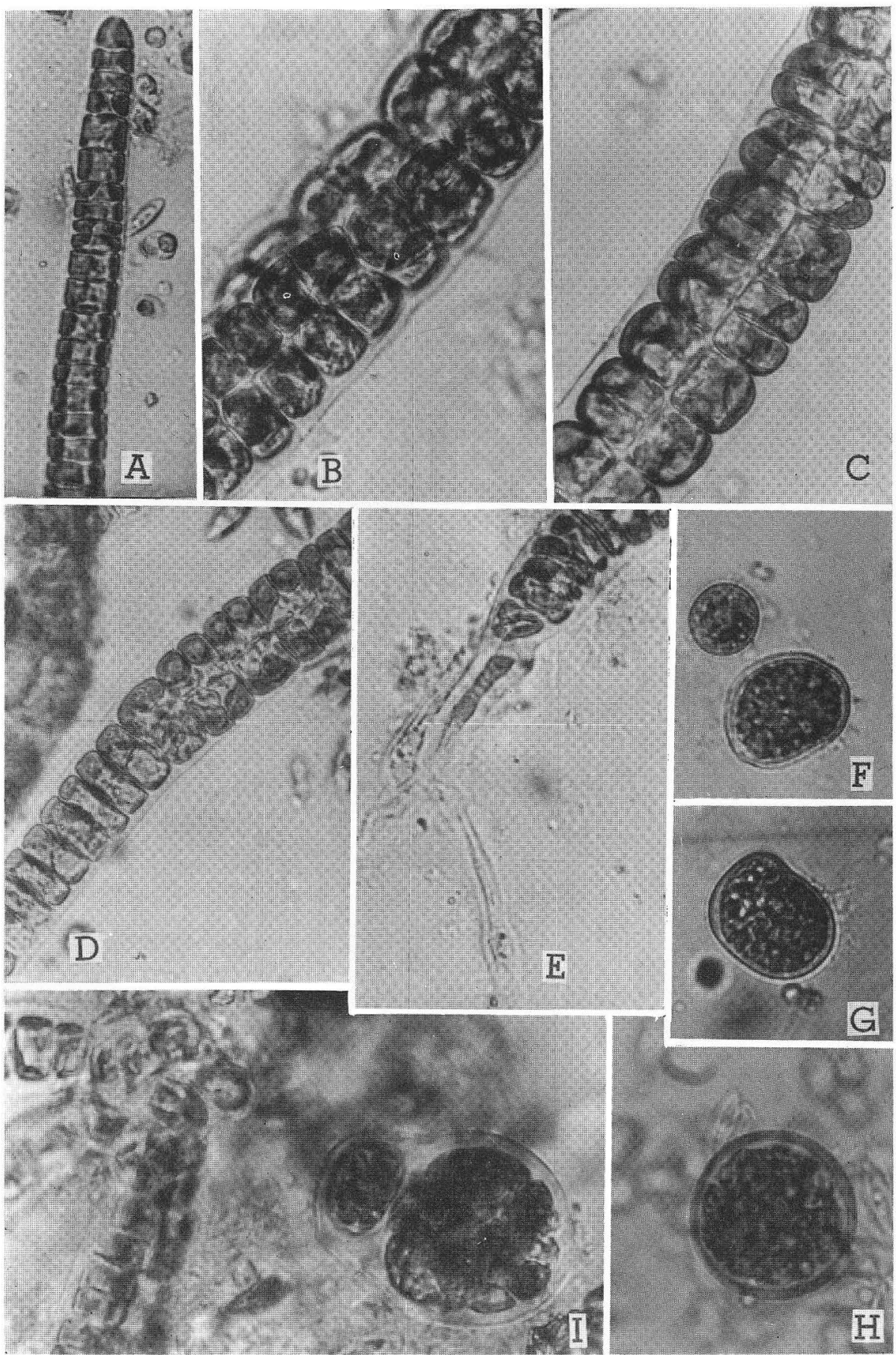

Fig. 6. Capsosiphon fulvescens. A-E: part of one and same thallus in about one-month-old germling obtained by culture, showing apical (A), middle (B, C), lower (D), and basal (E) portions. F-H: cyst-like cells obtained by culture. F-G: cyst-like cells, ca. 20-day-old. $\mathrm{H}$ : cyst-like cells, ca. 40-day-old. I : fertile cyst-like cell mixed with the germlings. A, D$\mathrm{E} \times 400, \mathrm{~B}-\mathrm{C} \times 600, \mathrm{~F}-\mathrm{I} \times 660$. 
and discharged isomorphic 2-flagellate gametes. The zygotes always developed into new thalli identical with their parents. He stated that it is more natural to consider the alga as having a closer relation to Percursaria and Enteromorpha rather than to Ulothrix and Monostroma, because of the absence of a zygote developing into a thick-walled zygocyst.

Migita (1967) studied the same species from Mogi near Nagasaki and found tha: both zoospores and gametes were produced on the same thallus. Four-flagellate zoospores grew into new thalli identical with the mother plant, whereas two-flagellate gametes conjugated to form zygotes which developed into unicellular cysts. The cyst discharged 4-flagellate zoospores which grew into multicellular thalli. He also observed that parthenogametes grew into unicellular cysts, but neither zygotes nor parthenogametes developed into multicellular thalli. He concluded that $C$. fulvescens had a closer relation to Monostroma and Ulothrix than to Ulva and Enteromorpha, and moreover, this species was more closely related to Ulothrix and Urospora than to Monostroma.

On the other hand, the results obtained in my studies : howed that both zygotes and parthenogametes of $C$. fulvescens developed into thalli identical with the mother thallus or into cyst-like cells.

BLIDING (1968) stated that Capsosiphon lacked rhizoidal cells characteristic of the Ulvaceae, and this fact was a reason of his removal of Capsosiphon from Ulvaceae to Capsosiphonaceae Chapman.

So far as the results obtained by Migrta and myself are concerned, there was no appreciable difference in the attaching cells of the germlings between Capsosiphon and the other members of Ulvaceae. However, I came to a conclusion now that Capsosiphon should be transferred from Ulvaceae to Capsosiphonaceae since $C$. fuiv scens is quite different in many respects from the members of three families, Ulvaceae, Monostromaceae and Ulotrichaceae, though Capsosiphon bears resemblance to Enteromorpha in its cylindrical adult thallus, to Monostroma more closely in its cellarrangement and life-history, and also to Ulothrix in its mode of swarmer-liberation and life-history.

TATEWAKI (1969) reported in his studies of Monostroma groenlandicum that (1) the gametes were discharged from a gametangium as a mass enclosed within a hyaline sac, (2) 2-flagellate gametes conjugated to form zygotes, (3) both zygotes and pathenogametes developed into unicellular cysts, (4) the cysts produced aplanospores, and (5) the aplanospores grew into multicellular thalli typical of the alga. $\mathrm{He}$ described this alga as a spccies of Monostroma, but suggested that the alga seemed to be intermediary between Monostroma and Ulothrix or Capsosiphon, because the process of life-history and the mode of swarmer-liberation were similar to those of Ulothrix and Capsosiphon. It is to be noted that $C$. fulvescens is closely related to $M$. groenlandicum in many respects. 

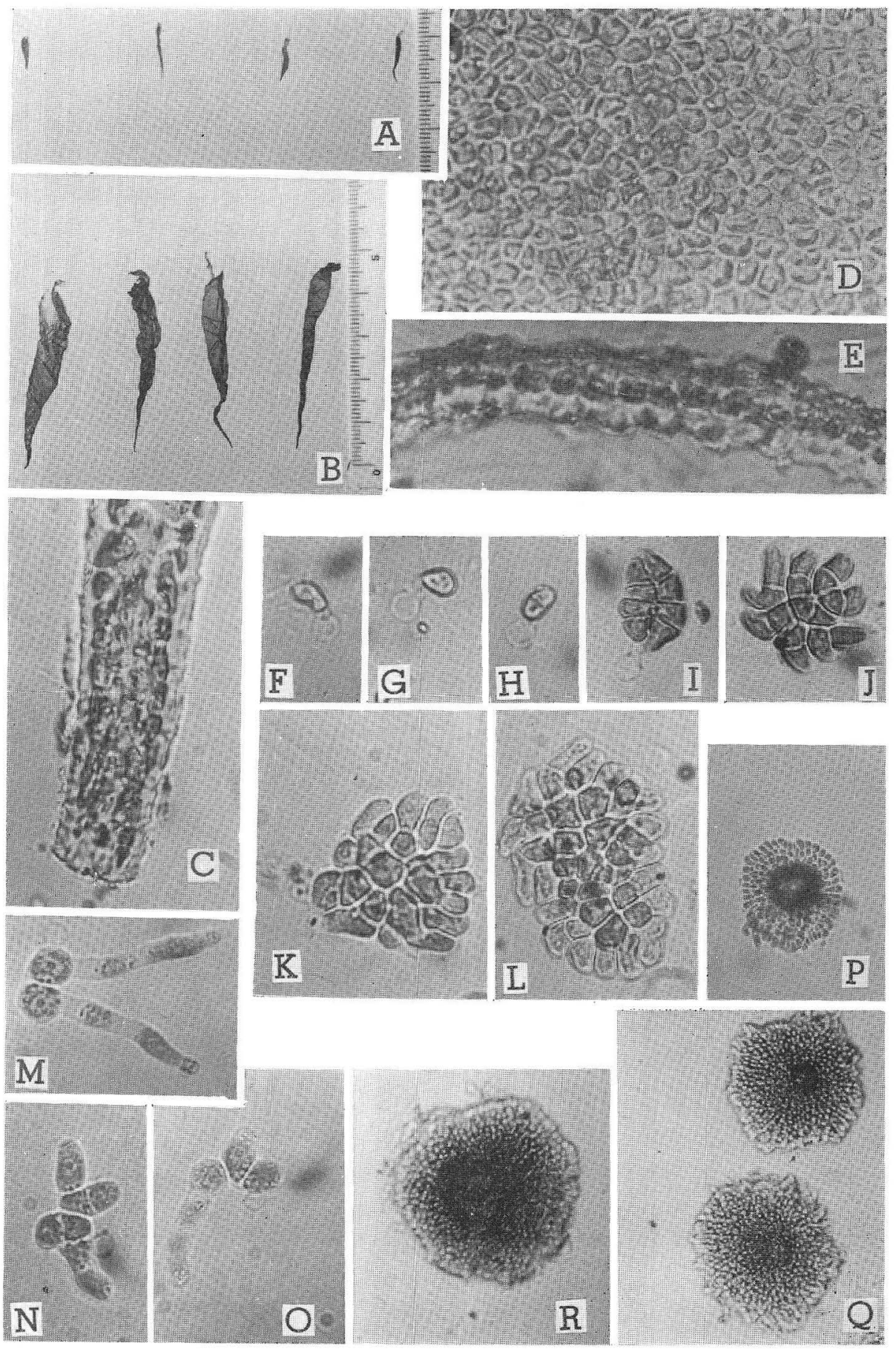

Fig. 7. Blidingia minima var. minima. A: adult specimens from near the high water mark. B: adult specimens from somewhat lower levels than those shown in A. C: surface view of the 


\section{B. Genus Blidingnia KYLIN 1947}

Thallus is always tubular, simple or sparsely branched, composed of very small cells, up to $10 \mu$ diam. in a surface view, which are arranged irregularly. Each cell has a chloroplast and one pyrenoid. The general appearance of the thallus is not different from that of Entermorpha, so the species of this genus, Blidingia minima, was formerly placed in Eneteromorpha. Working on the development of Enteromorpha minima, BLIDING (1938) reported that: (1) the swarmers were always 4-flagellate zoospores, (2) the zoospore at the first stage of its germination produced a long germination-tube, and the cell-content migrated into the tube, (3) the sporeling in its early development formed a disc, and (4) the disc later upheaved at the central part to form a multiseriate tubular body.

KyLiN (1947) established Blidingia on the basis of E. minima because of its pecurialities in the development of sporelings.

\section{Blidingia minima (NAEgeli ex KutzIng) Kylin var. minima}

Japanese name: Hime-aonori (Yamada \& TANAKA)

Kylin, 1947, p. 8; 1949, p. 30; Bliding, 1963, p. 23; Setchell \& Gardner, 1920, p. 249 (as Enteromorpha micrococca and E. minima); Collins, 1928, p. 121 (as E. minima and E. micrococca); OKamura, 1936, p. 14 (as E. micrococca); Yamada \& KandA, 1941, p. 221 (as E. nana var. minima); ARASAKI, 1946, p. 284 (as E. nana); 1964, p. 5 (as Blidingia nana); TокIDA, 1954, p. 50 (as E. nana var. minima).

This alga was growing densely on jetties and stones in the upper part of intertidal zone from winter to early summer at Suma, Akashi and Shirahama. The adult plants from near the high water mark were very small, $0.8-1.5 \mathrm{~cm}$ high, about $1.5 \mathrm{~mm}$ broad, while those trom lower levels were larger, $3-5 \mathrm{~cm}$ high, and $5-7 \mathrm{~mm}$ broad (Fig. 7. A, B).

The thalli are tubular, mostly simple but sometimes branched near the base, attached to the substratum by means of rhizoids, and rather soft in texture and wrinkled. In a surface view, the cells are rectangular or pentagonal in shape, 4-6 $\times 8-10 \mu$, and arranged irregularly. In a sectional view, the cells are roundish rectangular, 8-10 $\mu$ high, containing a chloroplast with a single pyrenoid, and their membranes are 17-20 $\mu$ thick (Fig. 7. D, E).

I carried out an investigation on the reproduction of this species in 1964, and

lower part of thallus showing rhizoidal processes of the cells. D: surface view of the middle part of thallus. E: part of cross-section through the middle part of thallus. F-G: two-dayold germlings in which cell contents have migrated into germination tube. $H$ : two-cell stage of germling. I : one-week-old germling which has already formed a disc. $\mathrm{J}: 10$-dayold disc. K-L: ca. two-week-old germlings which have begun to upheave in the center. M-O : elongated and branched germlings. P-R: disc-shaped germlings with a central erect sac. C-E $\times 600, \quad$ F-O $\times 660$, P-R $\times 200$. 


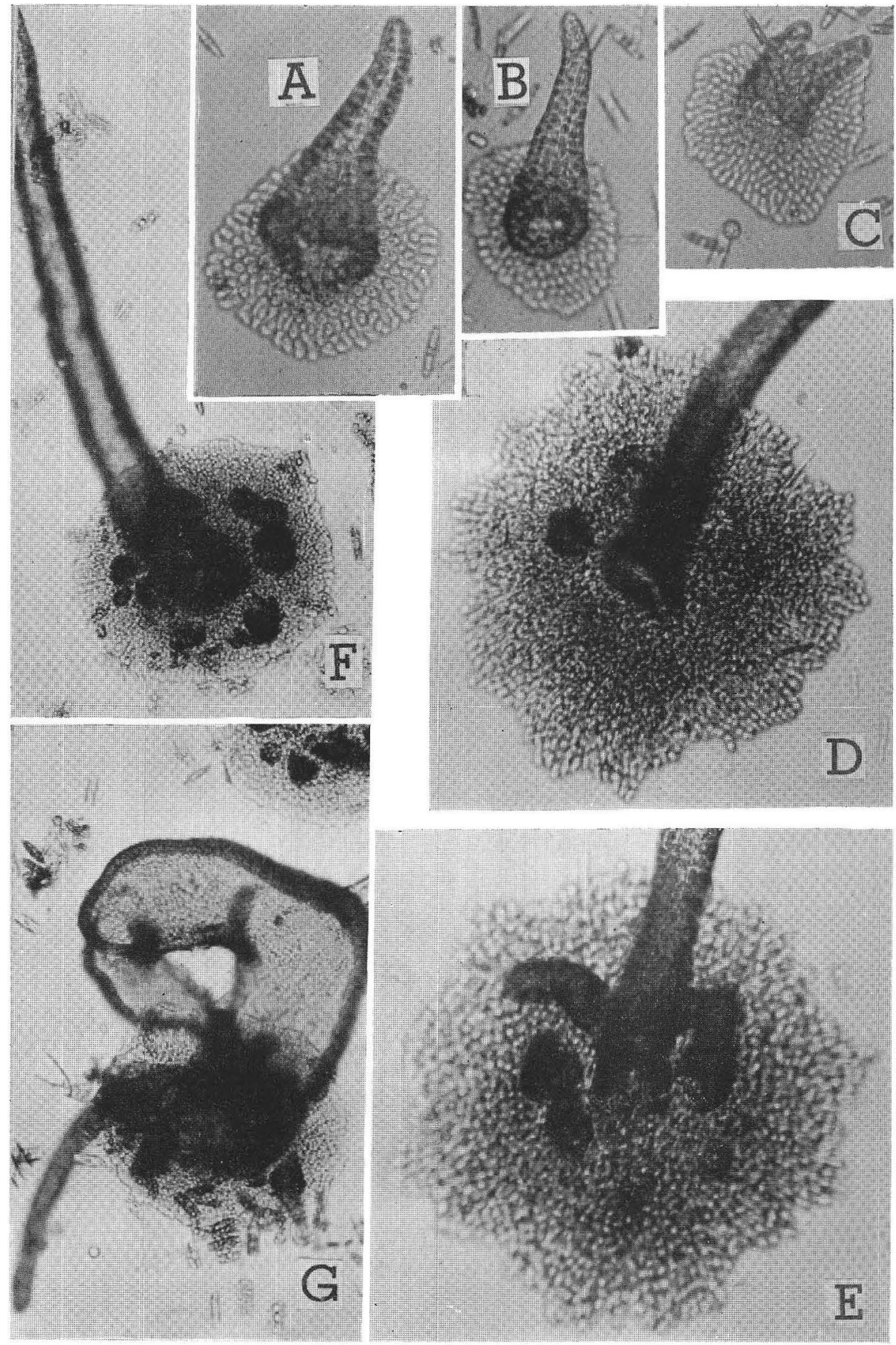

Fig. 8. Blidingia minima var. minima. A-C: 40-day-old germlings. A-B: disc-shaped germlings with a tapering tubular sac. C: germling with a double-headed tubular body. D-F : germlings with several young erect bodies besides the main erect thallus on the well developed disc. $G$ : two-month-old germling. A-C $\times 220, \mathrm{D}-\mathrm{E} \times 250, \mathrm{~F}-\mathrm{G} \times 150$. 
could always observe liberation of 4-flagellate zoospores from the fertile individuals collected in four months from February to May. The fact that this species produces only 4-flagellate zoospores has already been reported by BLiding (1938), YAMADA \& KANDA (1941) and ARAsaki (1946). Recently Bliding (1963) proposed, on the basis of his precise taxonomic study, to unite E. micrococca and E. nana and to refer it to Blidingia minima. B. minima var. minima agrees well with the alga described in the present thesis.

Reproduction and development: The 4-flagellate zoospores are various in shape, from elongate pear-shaped to nearly spherical or sometimes spindle-shaped (Fig. 9 . A). They are from $3 \times 7 \mu$ to $5 \times 9 \mu$ or $6 \times 8.5 \mu, 4.4 \times 8 \mu$ on an average, in size. They have no eyespot and lack phototaxis. As soon as discharged from the thallus, the motile zoospores became motionless and fastened to the substratum, and then rounded off and secreted a thin membrane. Soon the spore began to germinate (Fig. 9. B), producing a long germination tube to which the contents migrated
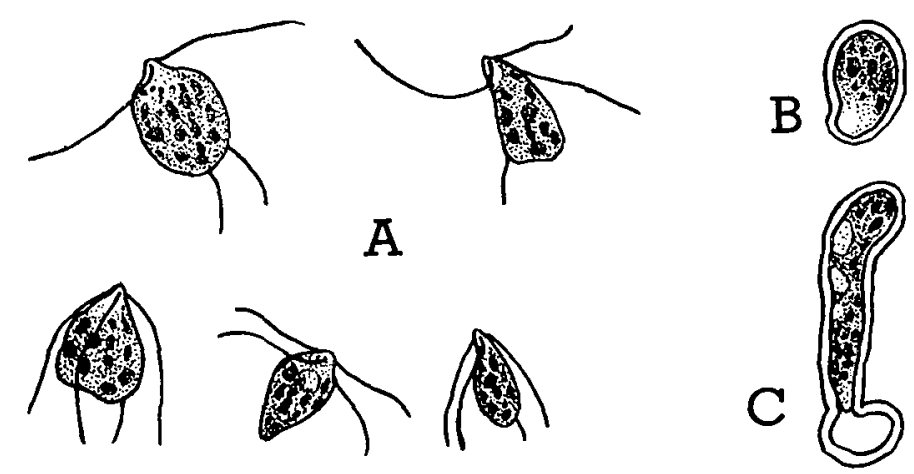

Fig. 9. Blidingia minima var. minima. A: zoospores. B: initial stage of spore germination. $\mathrm{C}$ : sporeling with cell contents migrated into tubular portion. A-C $\times 1500$.

gradually (Fig. 9. C). After two days, the whole contents of the spore migrated into the swollen terminal portion of the tube, leaving the initial cell cavity empty (Fig. 7. F, G). Three days after germination, the sporeling divided by a horizontal wall into two cells (Fig. 7. H). Then the sporeling became 3-5-celled after five days, 8-celled after one week, and 10-16-celled after 10 days (Fig. 7. I, J), forming a disc as the primary attachment organ in its early development. Sometimes the sporelings were observed to be branched with elongated cells (Fig. 7. M-O). Two weeks after germination, the discs began to upheave at the central portion where the cells were darker in color in their contents (Fig. 7. K, L). This upheaval of discs took place mostly when the discs were 15- to 50-celled but sometimes when they were much more developed and as large as $150 \mu$ in diam. (Fig. 7. Q). The upheaved portion developed into the erect bullate frond (Fig. 7. P-R) which became a tapered tubulous frond, about $170 \mu$ in height after 40 days (Fig. 8. A, B). Sometimes 
the erect frond was forked at the apex while very young (Fig. 8. G). The growth of both the erect frond and the disc continued and they became larger and larger. The two months old sporelings were about $500-600 \mu$ in height (Fig. $8 \mathrm{G}$ ). It was frequently observed that several row erect fronds were produced on a well developed disc besides the central erect frond (Fig. 8. D-G). Such a sporeling grows into an individual with the basal ramification. The erect frond usually produces at its base some horizontal outgrowths which form a secondary disc covering the primary disc and making the attachment of the sporeling more firm and stable. About 100 days after the start of the culture, the sporelings were found to have grown to young plants which attained the size as large as about $3.5 \mathrm{~cm}$ in height and about $3 \mathrm{~mm}$ in breadth.

The above described development of this alga agrees well with that reported by BLIDING (1938) in the material from Sweden and also with the results obtained by YAMADA \& KANDA (1941) in the material from Muroran and by ARASAKI (1949) in the material from Ise and Mikawa Bays. As pointed by YamadA \& Kanda, the present species is closely related with Monostroma zostericola in that (1) the discs are built and (2) the zoospores possess no eyespot.

Recently, Yamada \& TATEwaki $(1959,1965)$ discovered that both kinds of gametes are often discharged from one and same disc of $M$. zostericola. However, the liberation of gametes has not been observed yet in the present species.

[To be continued] 